\title{
Ernst Herzfeld, Joseph Upton, and the Artaxerxes Phialai
}

\author{
HENRY P. COLBURN
}

In 1935 Ernst Herzfeld (1879-1948), a pioneering-and controversial-archaeologist and philologist of ancient Iran, published four silver vessels bearing Old Persian inscriptions naming Artaxerxes I, ruler of the Achaemenid Persian Empire from 465 to 424 B.c. ${ }^{1}$ The authenticity of the inscriptions and of the vessels themselves (one of which is now in the collection of The Metropolitan Museum of Art [fig. 1]) was challenged immediately on philological grounds by Hans Heinrich Schaeder and W. B. Henning. ${ }^{2}$ Since then scholars have continued to question the inscriptions and, given his checkered career, usually imply that Herzfeld himself was the forger. A 1932 letter preserved in the archives of the Museum's Persian (later Iranian) Expedition written by Joseph M. Upton (1900-1981), at the time assistant curator of 


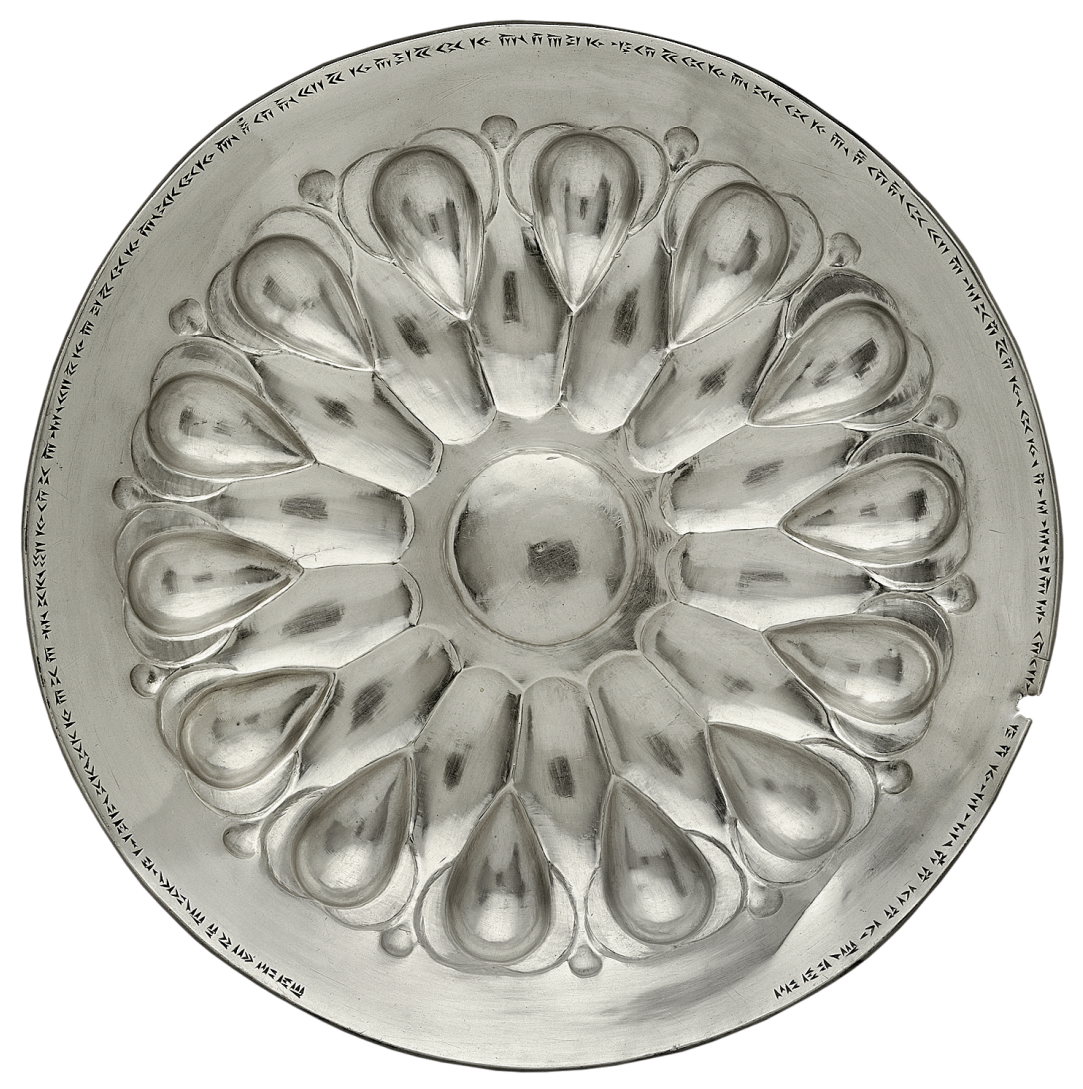

Near Eastern Art and a member of the expedition, casts new light on the authenticity of the inscriptions, the vessels themselves, and Herzfeld's role in their history.

The vessels published by Herzfeld are conventionally called phialai (singular phiale), using an ancient Greek term for any wide, shallow bowl. In addition to the example housed in the Metropolitan Museum, the three other phialai from the group are now in the British Museum, London; the Smithsonian Institution's Freer Gallery of Art, Washington, D.C.; and the Reza Abbasi Museum, Tehran. ${ }^{3}$ Although the four vessels vary slightly in size and weight, they are identical in form and inscription. Each has a carinated, or ridged, shoulder and a turned-out rim. In the center of each bowl is a raised boss, usually referred to by the Greek term omphalos, surrounded by fourteen tongue-shaped depressions. Between the depressions are deep, rounded lobes, or gadroons, and between these gadroons are smaller rounded lobes. The cuneiform inscription in Old Persian that runs around the interior of the rim reads "Artaxerxes, the great king, king of kings, king of lands, son of Xerxes the king, Xerxes son of Darius the king, the Achaemenid: in his house this silver bowl was made."' Herzfeld argued that the word translated here as "bowl" (bātugara) incorporates an Old Persian root (batu-) from which the modern Persian word for wine derives. According to this reasoning, the inscriptions designate the phialai as drinking vessels. ${ }^{5}$ The omphalos in the base of each vessel would have facilitated its use for drinking by making it easier to hold with one hand, with the middle finger hooked inside the indentation and the thumb stretched out to grip the vessel at or near the rim.

Recent technical research indicates that the phialai themselves are most probably ancient. ${ }^{6}$ The vessels were made by raising and sinking a single sheet of metal and then adding chased details, a method that was employed for most extant Achaemenid metalware of secure authenticity. Both X-ray fluorescence (XRF) and neutron activation analysis (NAA) have also shown that, like other examples of genuine Achaemenid silver, the metallic composition of each bowl is an alloy of silver and copper with traces of gold and lead. With a combined weight equal to 600 sigloi-the siglos being a silver coin minted by the Achaemenid kings-the four bowls were probably made as a set from a predetermined quantity of silver measured according to an ancient Persian standard. ${ }^{7}$ Visual examination of the inscriptions, including a recent inspection of the inscription on the phiale under consideration here, likewise suggests that the engraved marks were made prior to the vessels' burial (fig. 2). ${ }^{8}$ None of these lines of 
fig. 2 (a) Detail of inscription on phiale (fig. 1) with copper-oxide deposits indicated by arrows, original magnification, $\times 40$; (b) 3D scan of inscription detail highlighting engraving tool marks, original magnification, $\times 40$

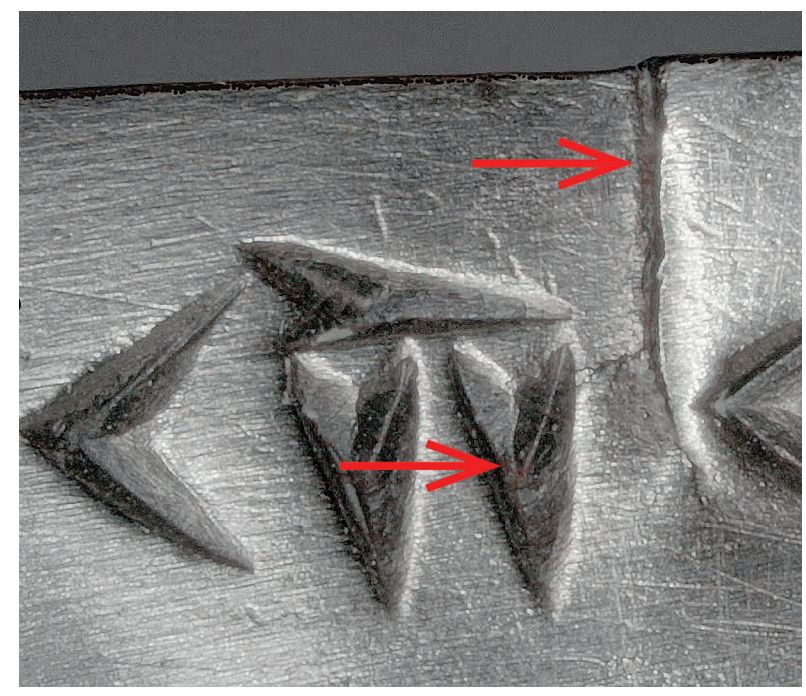

evidence independently constitutes proof of the vessels' authenticity, but taken together they are compelling. Yet in recent years the linguistic challenges to the authenticity of the inscriptions have been renewed by Nicholas Sims-Williams and Rüdiger Schmitt, once again insinuating that Herzfeld was the forger. ${ }^{9}$

Until the rediscovery of Upton's 1932 letter in the Museum's Persian Expedition archives, the earliest documented reference to the phialai appeared in one of Herzfeld's notebooks, now in the archives of the Freer Gallery of Art and the Arthur M. Sackler Gallery. During his travels and excavations in Iran, Herzfeld filled multiple notebooks, sketchbooks, and journals with records of the objects, monuments, sites, and inscriptions he encountered..$^{10}$ In the notebook labeled "Cuneiform" (Keilschriften) he copied and transliterated the inscription on the phialai, with the caption "silver bowls Hamadan, Oct. 1932" (Silberschüsseln Hamadan, Okt. 1932). ${ }^{11}$ He annotated a sketchbook drawing of one of the phialai, dated July 7,1934 , with the following:

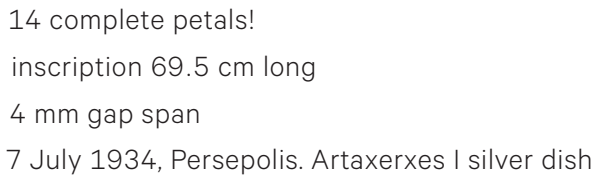

On the following page is a copy of the inscription. ${ }^{12}$ The annotations indicate that the drawing was made at Persepolis, where Herzfeld directed excavations on behalf of the Oriental Institute of the University of Chicago from 1931 to 1934. While the drawing and notes seem to be part of Herzfeld's work toward his publication of the vessels the following year, they might alternatively be interpreted as preparations for adding forged inscriptions to the ancient vessels, a project that would have been under way by October 1932 and

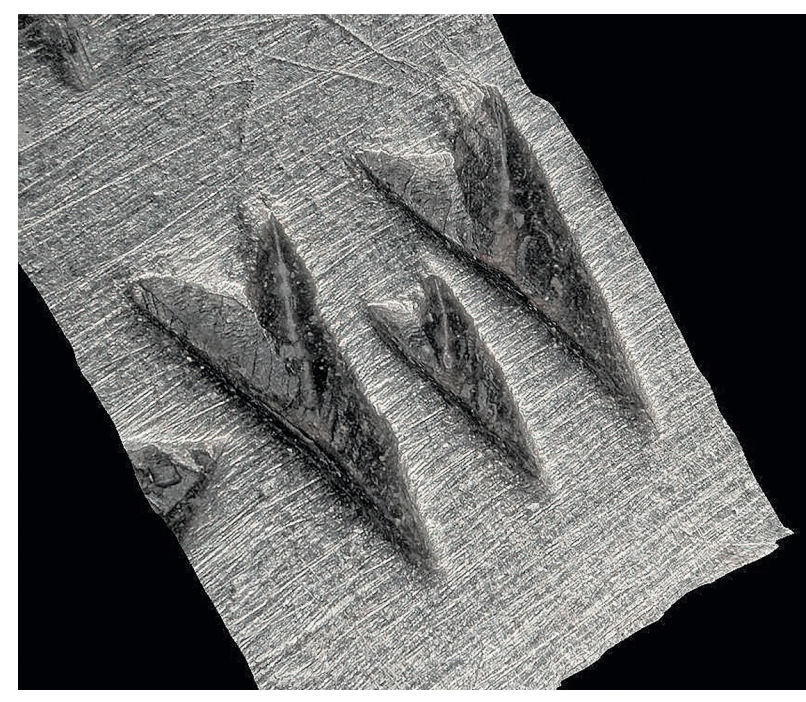

culminated in the 1935 publication and presumably the subsequent sale of the vessels. Herzfeld was one of the few people in the 1930 s who had the philological expertise necessary to forge an Old Persian inscription. He was also known to have sold antiquities that he had collected, as did many of his contemporaries. In this respect his legacy as an archaeologist is nothing if not complicated, though new archival research may indicate that many of the allegations of smuggling leveled against him are unfounded..$^{13}$

Upton's letter provides new evidence regarding Herzfeld's relationship to the inscriptions on these vessels. Upton was a member of the Metropolitan Museum's Persian Expedition from 1932 to $1946 .{ }^{14} \mathrm{He}$ first traveled to Iran in 1928 on a Carnegie Fellowship to study with Herzfeld and to participate in his fieldwork at Kuh-i Khwaja in Sistan the following spring. ${ }^{15}$ In 1932 he returned to carry out excavations on behalf of the Museum at Qasr-i Abu Nasr, a Sasanian and Islamic site near Shiraz, and he stayed with Herzfeld at Persepolis while making arrangements for the first field season. During this time Upton remained in regular contact with Maurice Dimand, curator of Near Eastern Art at the Metropolitan Museum, to report on his progress. In one of his letters to Dimand, dated October 24, 1932, he refers explicitly to the Artaxerxes phialai: "A dealer has for sale six silver plates which are grduated [sic] in size to fit into one another. The four smaller ones bear identical inscriptions in cuneiform stating that they were made for the palace of Artaxerxes I." ${ }^{16}$ This reference is confirmed by a photograph (fig. 3) of one of the phialai (it is impossible to determine which from the picture) that Upton included with his letter to Dimand. The description of the vessels as "graduated in size to fit into one another" also accords with the dimensions of the four inscribed Artaxerxes phialai, 
which have diameters of 29.5 (Freer), 29.2 (Metropolitan Museum), 29.0 (British Museum) and 26.2 (Reza Abbasi Museum) centimeters, respectively. The fate of the two largest, uninscribed bowls mentioned by Upton remains uncertain. ${ }^{17}$

This letter clarifies several questions surrounding Herzfeld's acquaintance with the Artaxerxes phialai. First, it confirms Herzfeld's claim, made in 1935 in a letter to Ernst Kühnel, director of the Museum für Islamische Kunst in Berlin, that he first encountered the phialai with Upton. ${ }^{18}$ Upton's letter provides a likely date for that encounter in October 1932, which is also when Herzfeld first recorded the inscription in his notebook. Indeed, Upton must have been with Herzfeld when he saw the phialai, because he could not have read the inscriptions himself. More importantly, Upton's letter attests that the phialai were already inscribed, meaning that Herzfeld could not have forged them.

The letter also may help to explain the Hamadan provenance for the phialai given in Herzfeld's Keilschriften notebook. Upton wrote that he met Herzfeld and Herzfeld's sister and nephew in Baghdad and drove with them to Persepolis. It also states that Upton had met with André Godard, director of the Iranian Archaeological Service, in Isfahan. Herzfeld's diary similarly indicates that he was in Isfahan on October 17 and 18, suggesting that he and Upton drove from Baghdad to Isfahan, and then on to Persepolis, an itinerary that would likely have taken them via Hamadan. ${ }^{19}$ Relatively few roads were suitable for car travel in Iran in the 1920s and 1930s, and all radiated from Tehran. The main route across the Zagros Mountains from Baghdad into Iran went by way of Kermanshah, Hamadan, Malayer, Arak, and Qom, where it met the major north-south road connecting Tehran to Isfahan and Shiraz. ${ }^{20}$ While the letter does not explicitly say that the party stopped at Hamadan, neither does it provide many details of the journey. Upton and Herzfeld might have seen the bowls in Isfahan, or

fig. 3 Photograph of an inscribed silver bowl (phiale) attached to Joseph Upton's letter to Maurice Dimand, dated October 24 1932. Persian Expedition Archives, Box 1, Department of Ancient Near Eastern Art, MMA indeed anywhere along their route. It was common practice for antiquities dealers to attribute objects to Hamadan (ancient Ecbatana) without basis, since the site was associated with the Achaemenid kings in Greek texts but had not been formally excavated. ${ }^{21}$ Herzfeld may then have recorded this alleged provenance in his notebook along with the inscription. Nevertheless, it is unlikely that Herzfeld discovered the vessels himself at Hamadan sometime in October 1932 (the date given in his notebook), or that he forged the inscriptions, since he was clearly traveling with his family and Upton immediately prior to encountering them.

Upton's letter thus permits a new reconstruction of Herzfeld's involvement with the phialai. Herzfeld first saw the vessels with Upton in October 1932 en route from Baghdad to Persepolis. While the annotated drawing in his notebook, dated July 1934, might indicate that he purchased them himself or that he came across them a second time, it is more likely that this drawing was only part of his preparations for publication, as it clearly served as the basis for one of the figures in his 1935 article. ${ }^{22}$ In fact, there is no evidence that Herzfeld ever owned or sold these vessels. The earliest attested owner is Arthur Upham Pope, a scholar and dealer in Persian art, who was in possession of at least one of the phialai by 1940, when he sold it to the dealer Joseph Brummer; this vessel was subsequently purchased from Brummer's estate by the Metropolitan Museum in $1947 .{ }^{23}$ If anyone would have benefited from adding a forged inscription to these vessels in order to increase their commercial value it would have been Pope, not Herzfeld. Yet Pope lacked the philological expertise necessary to forge such inscriptions, and, as Lindsay Allen notes, "one would have to imagine a collaboration in which the fake inscription were perhaps commissioned from Herzfeld by Pope and added to the bowls for the purpose of enriching their sellers." ${ }^{24}$ Given the well-documented rivalry between Pope and Herzfeld this is highly improbable. Thus, while Upton's letter does not prove that the inscriptions on the Artaxerxes phialai are authentic, it does present a significant challenge to the claim that Herzfeld forged them.

\section{ACKNOWLEDGMENTS}

I am grateful to Ann Gunter, Stefan Hauser, Yelena Rakic, and Margaret Root for their generous and invaluable feedback on this article.

HENRY P. COLBURN

Research Associate, Kelsey Museum of Archaeology, University of Michigan, Ann Arbor 


\section{NOTES}

1 Herzfeld 1935. For wide-ranging studies of Herzfeld's career, see Gunter and Hauser 2005

2 Schaeder 1935, pp. 489-94; Henning 1940, p. 501. Herzfeld (1937, pp. 5-17; 1938, pp. 113-15, 296-9) defended the authenticity of the inscriptions, and many scholars of Iranian philology have tacitly accepted them as genuine (Curtis, Cowell, and Walker 1995, pp. 150-51).

3 MMA 47.100.84; British Museum (1994,0127.1); Freer (F1974.30); the vessel now in the Reza Abbasi Museum was catalogued in Ghirshman 1961, no. 680.

4 Translation from Kuhrt 2007, p. 316.

5 Herzfeld 1935, p. 2. The term bātugara is not attested in any other Old Persian text, however, and is one of the bases on which the authenticity of the inscriptions has been challenged, though other scholars have accepted it as genuine (e.g., Lecoq 1997, p. 266).

6 Gunter and Jett 1992, pp. 70-72; Curtis, Cowell, and Walker 1995, pp. 149-50; Gunter and Root 1998, pp. 8-12, 13-15.

7 Vickers 2002, pp. 333-36.

8 I thank Jean-François de Lapérouse, conservator, Department of Objects Conservation, MMA, for providing the following observations:

Although the interior of this bowl has been completely cleaned of corrosion, remnants of reddish brown copper-oxide corrosion that formed on the surface during burial are still retained in a small crack in the rim and in the depths of several characters of the cuneiform inscription [fig. 2a]. Other characters retain dark gray deposits similar in appearance to the thick silver-chloride corrosion preserved on the reverse, and nondestructive $X$-ray diffractive spectroscopy scans of these deposits confirmed the presence of chloride not found on adjacent clean surfaces. Although not conclusive, these observations are consistent with the inscription having been made before the phiale was buried and significant oxidation began. Magnification also revealed tool marks, indicating that the inscription was made by engraving - a process of cutting and removing metal that was also used to make the inscriptions on the phialai in the British Museum and the Freer Gallery [Gunter and Jett 1992, p. 71; Curtis, Cowell, and Walker 1995, p. 150] While the displacement of metal by chasing is more typically found in ancient metalwork, the technique used here involved cutting down into the metal using a chisel in a slanted motion rather than pushing a $\mathrm{V}$-shaped graver across the surface, as is usually found in modern engraving. In addition, the wear evident around the top edges of the characters is consistent with age predating the modern era [fig. $2 \mathrm{~b}$ ]

9 Sims-Williams 2001, pp. 189-92; Schmitt 2007, pp. 82-93.

10 This material is now divided between the Metropolitan Museum and the Freer and Sackler Galleries. For overviews, see Root 1976 and Hennessey 1992.

11 Gunter and Root 1998, p. 7
12 Ibid., pp. 6, 12-13. The German original reads:

14 fertige rosette!

inschrift $69.5 \mathrm{~cm}$ lang

$4 \mathrm{~mm}$ bruchstabshöhe

7 Juli 1934, Persepolis. Artaxerxes I. silver dish

Bruchstabshöhe, translated loosely above as "gap span," may refer to the distance between the lobes. Based on the measurements given in Herzfeld's drawing, the sketch probably depicts the phiale now in the Reza Abbasi Museum, which is the smallest of the four.

13 Hauser n.d. (forthcoming). I am grateful to Stefan Hauser for sharing his paper with me prior to its publication. See also the papers in Gunter and Hauser 2005 for assessments of Herzfeld's legacy.

14 During the 1940s this role was a cover for Upton's work as an Office of Strategic Services (OSS) agent, codenamed "TIGER," in Iran; see Wilber 1986, pp. 132-34, and O'Sullivan 2015, pp. 214-15.

15 Upton 1970, pp. 13-37.

16 The letter is in the expedition archives in the Department of Ancient Near Eastern Art, MMA.

17 Arguably any uninscribed silver Achaemenid phiale with a diameter greater than 29.5 centimeters could be one of the vessels mentioned by Upton. For example, phialai in the British Museum (1998,0117.1; Simpson, Cowell, and La Niece 2010) and Walters Art Museum, Baltimore (57.1816; Hill 1949, p. 2) have diameters of 30.7 and 29.8 centimeters, respectively-large enough for the Freer phiale to fit inside either. The Walters phiale was in the possession of Arthur Upham Pope by 1939, when Pope sold it to Joseph Brummer (Brummer Gallery Records, New York, inventory card number N4491); as noted elsewhere, Pope was also the earliest documented owner of any of the Artaxerxes phialai (by 1940). The uninscribed British Museum phiale was purchased by T. L. Jacks in 1934, a fact reported by Pope in a letter (Allen 2016, p. 161); it was subsequently purchased by Brummer in 1938 (Brummer Gallery Records, inventory card number P15010). Jacks, an employee of the Anglo-Persian Oil Company, not only knew Pope but facilitated his removal of antiquities from Iran (Allen 2016, p. 152).

18 Gunter and Hauser 2005, pp. 29-30.

19 Gunter and Root 1998, p. 7.

20 Government of Iraq 1929, pp. 32-34; see further Clawson 1993. There was also a southern route to Isfahan via Ahvaz, but Percy Sykes described it in 1921 as "a caravan route just passable by laden mules," suggesting it was an unlikely route for a car journey; see Sykes 1930, p. 528

21 Oscar Muscarella (1980, pp. 31-35) discusses the popularity of Hamadan as a fabricated provenance for Achaemenid art.

22 Herzfeld 1935, pl. 3 bottom. I am grateful to Stefan Hauser for suggesting this interpretation.

23 Brummer Gallery Records, inventory card number N4513; Allen 2016, p. 159.

24 Allen 2016, p. 160n127. 
Allen, Lindsay

2016 “'The Greatest Enterprise:' Arthur Upham Pope,

Persepolis and Achaemenid Antiquities." In Arthur Upham Pope and A New Survey of Persian Art, edited by Yuka Kadoi,

pp. 127-67. Studies in Persian Cultural History 10. Leiden: Brill.

Clawson, Patrick

1993 "Knitting Iran Together: The Land Transport Revolution,

1920-1940." Iranian Studies 26, nos. 3-4, pp. 235-50.

Curtis, John E., M. R. Cowell, and C. B. F. Walker

1995 “A Silver Bowl of Artaxerxes I." Iran 33, pp. 149-53.

Ghirshman, Roman

1961 Sept mille ans d'art en Iran. Exh. cat. Paris: Petit Palais.

Government of Iraq

1929 Maps of 'Iraq with Notes for Visitors. Rev., enl. ed. London: Waterlow and Sons Limited for the Government of Iraq.

Gunter, Ann C., and Stefan R. Hauser, eds.

2005 Ernst Herzfeld and the Development of Near Eastern Studies, 1900-1950. Leiden: Brill.

Gunter, Ann C., and Paul Jett

1992 Ancient Iranian Metalwork in the Arthur M. Sackler Gallery and the Freer Gallery of Art. Washington, D.C.: Arthur M. Sackler Gallery and Freer Gallery of Art, Smithsonian Institution.

Gunter, Ann C., and Margaret Cool Root

1998 "Replicating, Inscribing, Giving: Ernst Herzfeld and

Artaxerxes' Silver Phiale in the Freer Gallery of Art." Ars Orientalis 28, pp. 2-38.

Hauser, Stefan R.

n.d. '“Völkische Beobachter:' Der Alte Orient im 3. Reich und eine Rehabilitation von Ernst Herzfeld." In Aus der Vergangenheit lernen: Altorientalistische Forschungen in Münster im Kontext der internationalen Fachgeschichte, edited by Ludger Hiepel and Hans Neumann. Investigatio Orientis 1. Münster: Zaphon. Forthcoming.

Hennessey, Colleen

1992 "The Ernst Herzfeld Papers at the Freer Gallery of Art and Arthur M. Sackler Gallery Archives." Bulletin of the Asia Institute 6, pp. 131-41.

Henning, W. B.

1940 Review of Archäologische Mitteilungen aus Iran, vols. 7-9. Bulletin of the School of Oriental Studies, University of London 10, no. 2, pp. 501-7.

Herzfeld, Ernst

1935 "Eine Silberschüssel Artaxerxes' I." Archäologische Mitteilungen aus Iran 7, pp. 1-8.

1937 "Die Silberschüsseln Artaxerxes' des I. und die goldene Fundamenturkunde des Ariaramnes." Archäologische Mitteilungen aus Iran 8, pp. 5-51.

1938 Altpersische Inschriften. Archäologische Mitteilungen aus Iran Ergänzungsband 1. Berlin: Dietrich Reimer.

Hill, Dorothy Kent

1949 "Catalogue of the Exhibition: Recent Accessions, Part I."

Bulletin of the Walters Art Gallery 2, no. 1, pp. 1-3.
Kuhrt, Amélie

2007 The Persian Empire: A Corpus of Sources from the Achaemenid Period. London: Routledge.

Lecoq, Pierre

1997 Les inscriptions de la Perse achéménide. Paris: Gallimard. Muscarella, Oscar White

1980 "Excavated and Unexcavated Achaemenian Art." In Ancient Persia: The Art of an Empire, edited by Denise Schmandt-Besserat, pp. 23-42. Invited Lectures on the Middle East at the University of Texas at Austin 4. Malibu, Calif.: Undena.

O'Sullivan, Adrian

2015 Espionage and Counterintelligence in Occupied Persia

(Iran): The Success of the Allied Secret Services, 1941-45. London: Palgrave Macmillan.

Root, Margaret Cool

1976 "The Herzfeld Archive of The Metropolitan Museum of Art." MMJ 11, pp. 119-24.

Schaeder, Hans Heinrich

1935 "Über einige altpersische Inschriften." Sitzungsberichte der Preussischen Akademie der Wissenschaften, philosophischhistorische Klasse, pp. 489-506.

Schmitt, Rüdiger

2007 Pseudo-altpersische Inschriften: Inschriftenfälschungen und moderne Nachbildungen in altpersischer Keilschrift. Österreichischen Akademie der Wissenschaften, philosophischhistorische Klasse, Sitzungsberichte 762. Vienna: Verlag der Österreichischen Akademie der Wissenschaften.

Simpson, St. John, M. R. Cowell, and S. La Niece

2010 "Achaemenid Silver, T. L. Jacks and the Mazanderan Connection." In The World of Achaemenid Persia: History, Art and Society in Iran and the Ancient Near East, edited by John Curtis and St. John Simpson, pp. 429-42. London: I. B. Tauris.

Sims-Williams, Nicholas

2001 "The Inscriptions on the Miho Bowl and Some Comparable Objects." Studia Iranica 30, no. 2, pp. 187-98.

Sykes, Percy

1930 A History of Persia. Vol. 2. 3rd ed. London: Macmillan.

Upton, Joseph M.

1970 Travels in Persia. Vol. 1. Downingtown, Pa.: Joseph M. Upton.

Vickers, Michael

2002 “'Shed No Tears?' Three Studies in Ancient Metrology." In Essays in Honour of Dietrich von Bothmer, edited by Andrew J. Clark and Jasper Gaunt, pp. 333-38. Allard Pierson Series 14. Amsterdam: Allard Pierson Museum.

Wilber, Donald N.

1986 Adventures in the Middle East: Excursions and Incursions. Princeton: Darwin. 